I 2 feet long and $3 \frac{1}{2}$ feet broad, with the wheels near the middle, each cart being drawn by a pair of bullocks. The mahaut (driver) of the elephant I was riding having halted the animal close up to the heap of boulders, there was just room left between the elephant and the chain for the carts to pass. These carts were the ordinary vehicles of the country, and under ordinary circumstances an elephant would no more think of "shying" at them than a London dray horse would think of shying at a cab. Yet as the carts went by one by one my elephant became more and more uneasy, and finally, in spite of the efforts of the mahaut to restrain her, mounted on the heap of boulders, at the risk (which, considering how cautious elephants are in treading on suspicious ground, I believe she must have seen quite as clearly as the mahaut or I) of rolling down the slope below the road, if the rounded boulders shifted and gave way beneath her weight. It was some time before I perceived the cause of her fear. Elephants, even in India, are uncommon, and bullocks, as well as other domestic animals, generally feel considerable dread of them from their unusual appearance as well as their size. The bullocks in question were greatly frightened at having to pass so close to the bulky brute, and several of them in passing tried to get away from her by jumping the drain. It required all the efforts of the drivers to prevent their doing it. The elephant evidently saw that the bullocks were frightened and that they were trying to jump the drain, and she further calculated that if they did so the long tail of the cart would swing sharply round in the opposite direction and strike her violently across the fore legs. Of the two risks she preferred that of mounting on the heap of boulders.

Calcutta, July

As NATURE frequently contains notices of intelligence in animals, I have ventured to send you the inclosed note from the Reading local paper, as containing a remarkable fact regarding intelligence in a blind horse. The writer, Mr. Gostage, is quite trustworthy, and I have taken pains to verify the truth of his statements.

128, Oxford Road, Reading, August 6

Note PUblished in the Reading Observer of August 4, 1883

Sagacity of the Horse

SIR, - A circumstance so fully illustrative of the sagacity of the horse was witnessed in the neighbourhood of Mortimer last Saturday, and reported to me through the owner, that I think it worth publicity. I can vouch for its truthfulness, and if any doubt arises I can introduce such doubter to the owner. The hor e under notice, an old blind one, belonging to a small tradesman and farmer, was turned out to graze on the common near the owner's house. For some cause it wound its way through lanes to the blacksmith's, where he had often been before. The entrance to the forge is difficult of access on account of the ditche on either side, but the animal reached it safely, took its stand by the forge, and then neighed. The blacksmith, being at work in his garden, and hearing a horse neigh, looked for it, and not seeing it, returned to his gardening operations. In a short time he heard it again, but could not see a horse anywhere, until he went into his shop, when he found it standing very quietly by the forge as if waiting to be shod. Thinking some one must have brought it there, the blacksmith looked at its feet, and found one with the shoe presing into the frog, causing great pain. He then put on another shoe, and sent the horse back to its owner.

This instance of sagacity is so clear and telling that $I$ thought it desirable to ask you, Mr. Editor, to publish it. Yours truly,

King's Street, Reading, August, 1883

S. Gostage

ACCOUNTS are not rare of female cats having adopted the young of other creatures when deprived of their own, or while nursing their own young, but I have never met with a case like the following :-

My tom cat, Smut, whose eighteenth birthday was lately celebrated, has always been kind to kittens; and a long friendship with a tame rabbit was only terminated by the death of the rabbit in consequence of eating too much plum pudding one Christmas. But his benevolence to feathered creatures was first shown in $188 \mathrm{I}$, when, having a solitary chick hatched out of a clutch, I bethought me of making him useful as nurse, and with some fear put the chick into his basket. The experiment answered admirably, except that Smut sometimes licked the feathers the wrong way; and when about a fortnight afterwards the chicken was accidentally killed, it was curious to see its foster-father's search for it during the following three or four days.

Since then Smut has taken charge of as many as fifteen young chickens at a time, but he has never evinced the same affection for them as for his first feathered foster-child.

The Orphange, Wandsworth Road, August 7 J. DE B. F. P.

\section{Different Sources of Illumination}

In your issue of July 19 you give in the "Notes" (p. 28I) some interesting data as to the products of combustion and heat produced by different sources of illuwination, each being of 100 candle-power and giving off this light for one hour. This is valuable information, and I am sure that others besides myself would be glad if you could give a reference to the authority. I would also suggest that it would te interesting to have a comparative authoritative statement as to the carbonic acid and heat produced in the same time by an average human being. I was told the other clay by a mining engineer that he finds that one oil-lamp contaminates the air to the same extent as one miner when at work. It is often stated that one gas-burner in a theatre is as deleterious as six members of the audience. If the true state of the case were published in your columns, it would be interesting to many.

34, Great George Street, Westminster, July 20

[The information is based on an article in lia Lumière Électrique for June I6. -ED.].

\section{A Remarkable Form of Cloud}

AN account, which will I believe be found satisfactory, of the formation of the type of cloud described in NATURE (vol, xxviii. pp. 299, 320), will be found in a paper read by me before the Meteorological Society on June 20 last, and which will be published in the next Quarterly Journal of the Society. The paper is on "The Structure of Cirro-filum, or Ice-cloud disposed in Threads." A very valuable contribution to our knowledge on this subject will also be found in an article by Dr. Linn ("Ueber die Entstehung der Wolkenstreifen," Zeitschrift für Meteorologie, xviii. 52), to which I would refer those of your readers who are interested in the topic.

The cloud is very common, and regular reports of the direction both of movement and of "filature," elements of very considerable value in the prognosis of weather, have been, for some years past, sent to the Meteorological Office by a limited number of observers.

W. Clement Ley

\section{Disease of Potatoes}

WiEx I read the note from Naturen in NATURE, vol. xxviii. p. 28I, it appeared to me that Herr Anda was describing the same effects in the potato stalk as had been described by Berkeley in I846. In his description of the usual potato disease Berkeley says:- "The stem now rapidly putrefies, the cuticle and its subjacent tissue become pulpy, and separate when touched from the woody parts beneath. The whole soon dries up, and in many instances exhibits in the centre the black, irregular fungoid masses which are known under the name of Sclerolium varium, and which are believed to be the mycelium of certain moulds in a high state of condensation."

Now the Sclerotium varium grows exactly as described by Herr Anda; but so far as it has appeared here, it does not seem to be truly parasitical, but only begins to be developed on the potato stalks when they are dying down of the common disease. Whether this Sclerotium is the same as that referred to by $\mathrm{Mr}$. W. G. Smith (NATURE, vol. xxviii. p. 299) I do not know, but probably it is. He says he did not get bis to germinate; while Herr Anda describes the fruit of the Sclerotia found at Stavanger.

From "pink eye" potato stalks of last year I threshed cut a quarter of a pound of Sclerotium varium, and at the present time I have hundreds of specimens germinating in the way Herr Anda describes; one stalk only has yet come to what I regard as the perfect fructification, having developed at the apex a beautiful little cup; but about a score of others of those first 